\title{
Political participation of communities in the Legislative General Elections (Pemilu)
}

\section{Partisipasi politik masyarakat pada Pemilihan Umum (Pemilu) legislatif}

\author{
Rahmawati Halim ${ }^{1}$, Muhlin ${ }^{1} \&$ Rudi Salam ${ }^{2}$ \\ ${ }^{1}$ Department of Public Administration, Faculty of Social and Political Sciences, Universitas Tompotika \\ ${ }^{2}$ Department Public Administration, Faculty of Social Sciences, Universitas Negeri Makassar \\ Address: ${ }^{1}$ Karaton, Luwuk, Kabupaten Banggai, Central Sulawesi 94711 \\ ${ }^{2}$ Jalan AP Pettarani, Tidung, Rappocini, Makassar, South Sulawesi 90222 \\ E-mail: rudisalam@unm.ac.id
}

\begin{abstract}
The active involvement of the community at all stages of the election is very much needed, because our voice has an important value for the quality of democracy. The purpose of this study was to determine the extent of the political participation of the community in the legislative elections held in the electoral district of Banggai III in Banggai District. This research was conducted in Banggai III election area, which consists of 6 districts; Bualemo, Pagimana, Lobu, Bunta, Nuhon, and Simpang Raya. The study population amounted to 101,296 people. The samples were taken using cluster sampling and random sampling, with a $5 \%$ margin of error criteria. The total sample was made up of 236 people. The type of research methodology was a survey. The data was analysed using descriptive and inferential analysis. The methods of data collection were observations, in-depth interviews and questionnaires. The results showed that the political participation of the community involved seven variables: 1) the social and economic status of society, 2) geographic situation; 3) parental affiliation; 4) organisational experience; 5) political knowledge and awareness; 6) trust in the Government and 7) mass media socialisation and informal discussions. The social and economic status variables of the community, the experience of community organising and the trust in the Government should be taken seriously by the Regional Government and the $K P U$. While the models can provide positive nuances in relation to the political participation of the community such as a model capable of providing nuances such as 1) an improvement in social and economic status, 2) increased access regarding the geographical situation, 3) empowering community groups and affiliated politics, 4) improving the organisational experience of the community, 5) increasing public awareness, 6) increasing public trust to Local Government and $D P R D$, and 6) empowering mass media and informal discussions.
\end{abstract}

Keywords: politics participation; legislative general election

\section{Abstrak}

Keterlibatan aktif masyarakat dalam seluruh tahapan Pemilu sangat dibutuhkan, karena suara kita memiliki nilai penting bagi kualitas demokrasi. Penelitian ini bertujuan untuk mengetahui sejauh mana partisipasi politik masyarakat dalam pemilihan legislatif di daerah pemilihan Banggai III di Kabupaten Banggai. Penelitian ini dilakukan di daerah pemilihan Banggai III yang terdiri dari 6 kecamatan, seperti; Bualemo, Pagimana, Lobu, Bunta, Nuhon, dan Simpang Raya. Populasi penelitian berjumlah 101.296 orang. Sampel penelitian diambil dengan menggunakan cluster sampling dan random sampling yang menggunakan kriteria 5\% margin of error, dan total sampel penelitian adalah 236 orang. Jenis penelitian adalah survei. Data dianalisis dengan menggunakan analisis deskriptif dan inferensial. Metode pengumpulan data menggunakan observasi, wawancara mendalam, dan kuesioner. Hasil penelitian menunjukkan bahwa partisipasi politik masyarakat dari ketujuh variabel telah berpartisipasi positif dan signifikan, adapun variabel tersebut: (1) status sosial dan ekonomi masyarakat, (2) situasi geografis; (3) afiliasi orang tua; (4) pengalaman organisasi; (5) pengetahuan dan kesadaran politik; (6) kepercayaan kepada Pemerintah; dan (7) sosialisasi media massa dan diskusi-diskusi informal. bahwa variabel status sosial dan ekonomi masyarakat, pengalaman berorganisasi masyarakat, dan kepercayaan kepada Pemerintah hendaknya menjadi perhatian serius dari Pemerintah Daerah dan KPU. Sedangkan model yang mampu memberikan nuansa positif dalam partisipasi politik masyarakat seperti: model yang mampu memberikan nuansa positif seperti: 1) Peningkatan status sosial dan ekonomi, 2) Peningkatan akses situasi 
geografis, 3) Pemberdayaan kelompok masyarakat dan berafiliasi politik, 4) Peningkatan pengalaman berorganisasi masyarakat, 5) Peningkatan kesadaran politik masyarakat, 6) Peningkatan kepercayaan masyarakat kepada Pemerintah Daerah dan DPRD, dan 6) Pemberdayaan media massa dan diskusidiskusi informal.

Kata kunci: partisipasi politik; pemilihan umum legislatif

\section{Introduction}

As one of the democracy tools, general elections are conceptually considered to be capable in changing the concept of abstract sovereignty into a concrete concept (Goodnow 2017, Holik 2012, Niswati 2015, Prasetyoningsih 2014, Saraswati 2014, Trantidis 2017). The election results consist of elected people who represent society and who work for and on behalf of the people (Effendi 2017, Waiswa \& Phelps 2017). The procedure in terms of selecting a leader is by involving as many people as possible. This has defeated the popularity of selecting a leader via direct appointment or doing so via limited selection. Thus, an election is a front door for the change to prompt the people to create leaders who have the ability to make appropriate policies to improve societal conditions (Abdussamad, Akib \& Paramata 2015, Farida 2017, Mulyadi \& Amin 2017, Saggaf et al 2014). The active involvement and participation of the people is required. The more critical and higher the awareness of the society involved, the more this will lead them to better conditions through the election. Every vote is important for democracy, for the sake of development and improvement (Supriyanto 2014).

Societal involvement involves ensuring that they have been registered as a voter, researching and studying candidates, following and supervising the implementation of the campaign, reporting violations of the organisers and participants, finding out about the potential leaders and voting on the election day (Akib \& Salam 2016, Murdi \& Salam 2012, Salam, Rosdiana, Suarlin \& Akib 2014). The General Election (Pemilu) is one of the democracy pillars that places the society as a subject involved in the implementation of democracy itself. Until now, an election is still considered to be an aspect that can guarantee the political rights of the society as the most important element in the election is the political participation of the people. In the democratic government system, the people have absolute power, which means that the people's choice determines their leader. The government is created by society and the people reflect the people's hopes and trust (Humaeni 2014, Sahab 2017).

Based on that perspective, regarding the elections held in Indonesia between 1999 and 2009, the people's political participants decreased from time to time, significantly in general. The participation rate continued to decline from 92 percent (\%) in the 1999 Election to 84 percent (\%) in 2004. This continued to decline when the 2009 Election was held, which was only 71 percent (\%). Consistently, the average decline in the three election periods was +10 percent (\%). Moreover, this is KPU's duty, as the main institution to ensure the people's participation in the election in order to prevent abstention, which remain high. Notwithstanding the declining tendency, the central KPU is targeting the increase in the people's participation, as in the 2014 election, up to $75 \%$. This target is part of the election organisers' attitude and commitment to strengthening the legitimacy of the election administration, even though it is considered to be quite heavy (Setio 2014).

Furthermore, the declining political participation can be seen through the statements made by the Minister of Home Affairs, Gamawan Fauzi. In the 2004 Election, he had 148 million voters, and those who abstained made up 6.70 percent. The 2009 election voters reached 171.2 million, and those who abstained reached 15.93 percent. Gamawan, who is also the former governor of West Sumatra, also cited the survey results from the survey institutions regarding the public interest in participating in the 2014 Legislative Election. Those who were interested reached $79 \%$, those who were not interested reached $16 \%$ and those who said they did not know reached 5\% (Komisi Pemilihan Umum 2014). Furthermore, the Indonesian Institute of Sciences (LIPI) reported that 60 percent of the survey respondents, from 1,799 respondents in 31 provinces, said that they were less interested and not interested in politics at all respectively (Wanma 2015). 
The aforementioned phenomenon also occurred in the Electoral District of Banggai III during the Legislative Election on April 9th, 2014, where 101,296 people were registered as Permanent Voters (DPT); $47.70 \%$ did not participate and use their vote. Therefore, to find out the cause of this massive abstentions in the Electoral District of Banggai III, the researchers are interested in conducting more in-depth research on the significant number of voters casting ballots in the legislative election of April 9th, 2014.

Based on the narrative described, the research questions of this study are as follows. 1) What is the description of the political participation of the people in the Legislative General Election on April 9th, 2014 in the Electoral District of Banggai III, Banggai Regency? and 2) What factors influenced the decreasing rate of political participation in the Legislative General Election on April 9th, 2014 in the Electoral District of Banggai III, Banggai Regency? Furthermore, the research that will be planned to be carried out for two years (24 months) in the Electoral District of Banggai III is an attempt by the researchers to analyse and examine more deeply the political participation of the community in the implementation of legislative elections. The objectives of this study are as follows: a) to find out the description of the political participation of the people in the Legislative General Election (election) on April 9 $9^{\text {th }}, 2014$ in the Electoral District of Banggai III. In terms of future system development, this study will be a meaningful input for the Banggai Regency and Banggai Regency legislative governments related to making decisions about community involvement in politics as well as evaluating the electoral system. This influences election effectiveness and community responsibility for the election of representatives to the DPR. DPRD, and DPD and b) to determine the factors that significantly influence the decline in the political participation of the people in the Electoral District of Banggai III in the legislative elections on April 9th, 2014. This is so then a formula can be found that can be a 'panacea' to increase the political participation of the community, especially in the Electoral District of Banggai III, in the wider context of the legislative and presidential elections over the next five years. In addition, in the short term, it is expected that the political participation of the people in the Electoral District of Banggai III will increase, especially when facing the Regional Head elections which will be held simultaneously in 2015 and 2019.

\section{Research Method}

The method of this research is a survey using a quantitative approach (Creswell 2014). This research will contribute a generalisation to the higher population (Sarwono 2006). The research study was located in the six sub-districts of the Electoral District of Banggai III: Pagimana, Bualemo, Bunta, Nuhon, Simpang Raya, and Lobu. This research was carried out for six months (June 2016 through to October 2016). According to Arikunto \& Jabar (2009), the population was the whole subject of research. The population in this study was the society of Banggai III electoral district registered on the Permanent Voter List (DPT), referring to those who legally can cast ballots. This is as many as 101,296 people spread across the six districts. In order to determine the research sample from such a large population, the researchers used the following formula:

$$
\left(N=(p \times q) \cdot Z^{2}\right) / E^{2}
$$

$\mathrm{Z} \quad=$ Refers to $\mathrm{Z}$ value (level of trust). If there is a confidence level reaching $90 \%$, then the $z$ value is 1.65 . If the confidence level is $95 \%$, then the $z$ value is 1.96 , while the confidence level is $99 \%$, and the $z$ value is 2.58 .

$(\mathrm{pxq}) \quad=$ The population variation. Population variations are shown in proportion. The proportion is divided in half by $100 \%$ (or 1 ). The proportion has a high diversity if

$\mathrm{p} \quad=81.03 \%$ or 0.81 and $\mathrm{q}=18.97 \%$ or 0.19 .

$\mathrm{E}=$ Sampling error is $5 \%$ or 0.05

$\mathrm{N}=$ The population number

The calculation results from the formula above are as follows:

$=\left((0,81 \times 0,19) \cdot 1,96^{2} / 0,05^{2}\right.$

$=236,48=236$ respondents 
Based on the total respondents, to represent the six sub-districts, the researchers conducted the data collection distributed across the 250 polling stations randomly.

As for the data collection, the research instruments used were observations and interviews, as well as a questionnaire. Descriptive analysis was used to measure the level of community political participation consisting of five sub-variables, namely a) voting, b) political discussion activities, c) campaign activities, d) activities related to forming and joining other interest groups, and e) individual communication with political officials using frequency tables and percentages $(\%)$.

Qualitative analysis is one which does not use mathematical, statistical or other econometric models. The analysis is limited in relation to the used data processing techniques, such as tabulation and data checking, reading the available tables and numbers, and converting it through interpretation and descriptive activities. The inferential analysis is a combination between correlation analysis and multiple regression (multiple regression), which functions to determine the impact of the dependent variable within the independent variables related to the factors that influenced the public's political participation in the legislative election on April 9 ${ }^{\text {th }}, 2014$ in the Electoral District of Banggai III, Banggai Regency.

The variable relations analysis was conducted by using product moment correlation statistics to test hypotheses 1 to 7 , the influence between variables $X_{1,2,3 \ldots 7}$ (the society social and economic status (X1), condition / geographical (X2), political affiliation of the parents (X3), organisational experience (X4), political awareness (X5), trust in the government (X6), and mass media socialisation and informal discussions (X7) toward variable Y (community political participation) with a significance level of 5\%. Correlation was explained based on yxy formula (Sugiyono 2010) as follows:

Where:

$$
r_{x y}=\sqrt{ }(\Sigma X Y /([(\Sigma X 2)(\Sigma Y 2)]))
$$

$r_{x y} \quad=$ Correlation coefficient between variable $X$ and variable $Y$

$\Sigma x y=$ The total products of variable $X$ and variable $Y$

$\Sigma X 2=$ The total of squares of variable $X$

$\Sigma \mathrm{y} 2=$ The total of squares of variable $\mathrm{Y}$

In addition to these formulas, the following formula can also be used:

$$
r x y=\sqrt{ }\left((N \Sigma X Y-(\Sigma X)(\Sigma Y)) /\left(\left[\left(N \Sigma X^{2}-(\Sigma X)^{2}\right]\left[N \Sigma Y^{2}-(\Sigma Y)^{2}\right]\right)\right)\right.
$$

This product-moment correlation was used to calculate the strength of the relationship between one variable and another. The correlation analysis had various prerequisites that must be met, including the normal distribution of research data and interval data. Both of these conditions were normalised through a computer statistics program (Minitab), where each indicator representing the tested variables was combined to produce an interval score. From this score, the calculations of the correlation were generated.

This product-moment correlation was used to calculate the strength of the relationship between one variable and another. The correlation analysis had various prerequisites that must be met, including the normal distribution of research data and interval data. Both of these conditions were normalised through a computer statistics program (Minitab), where each indicator representing the tested variables was combined to produce an interval score. From this score, the calculations of the correlation were generated. The multiple linear regression equation was as follows:

The multiple linear regression equation was as follows:

$$
\mathrm{Y}=\mathrm{a}+\mathrm{b} 1 \mathrm{X} 1+\mathrm{b} 2 \mathrm{X} 2+\ldots+\mathrm{bnXnY}
$$




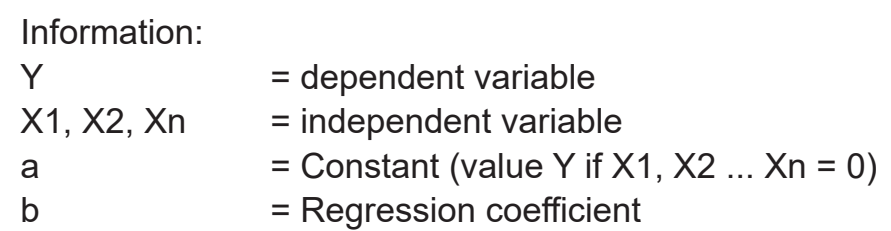

Source: Eriyanto (2007)

\section{Result and Discussion}

To find out the factors that influenced political participation in the Legislative General Election on April 9th, 2014 in the Electoral District of Banggai III, a simple regression analysis and multiple regression analysis was conducted to determine the impact of the independent variable (X1 .... X7) toward the dependent variable (Y). The tested hypothesis was $\mathrm{H} 0$, to explain whether there is an influence from the independent variables both individually and simultaneously.

\section{Social status and economics}

The results of the research used a simple regression equation, i.e $\mathrm{Y}=9.64+1.16 \mathrm{X} 1$. This means that from the results of the $t$ test, it was known that there is a positive influence on the social and economic status of the community towards the political participation in the Electoral District election of Banggai III. Furthermore, the results of the analysis of Variance (Test F) showed that there is a positive and significant influence between the variable of social and economic status of the community on the political participation of the people in the Electoral District of Banggai III. Thus, H1 is accepted and is rejected by Ho. The results of the analysis of variance are as follows:

Table 1.

The summary of $\mathrm{F}$ test result (Anova)

\begin{tabular}{lrrrrr}
\hline \multicolumn{1}{c}{$\begin{array}{c}\text { Variance } \\
\text { Source }\end{array}$} & \multicolumn{1}{c}{ SS } & \multicolumn{1}{c}{ DF } & \multicolumn{1}{c}{ MS } & $\mathbf{F}_{\text {arithmetic }}$ & $\mathbf{F}_{\text {tab }}$ \\
\hline Regression & 3456,8 & 1 & 3456,8 & 9,65 & 3,89 \\
Residual & 809,2 & 234 & 3,5 & & \\
\hline
\end{tabular}

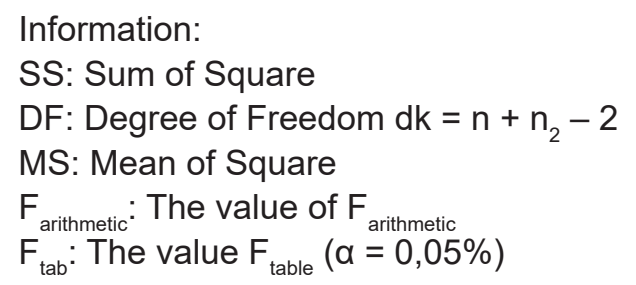

The $\mathrm{F}$ test results obtained that $\mathrm{F}_{\text {arithmetic }}$ value $>\mathrm{F}_{\text {table }}(0.05)$ which $\mathrm{F}_{\text {arithmeti }} \mathrm{c}$ is 9.65 and $\mathrm{F}_{\text {table }} 3.89$ at significance level $\alpha=0.05$.

\section{The situation and geographic condition}

The results of the study obtained a regression equation, namely: $\mathrm{Y}=8.13+1.10 \mathrm{X} 2$. The results of the $t$ test are that there is a positive influence on the geographical situation variable related to the political participation of the people in the Electoral District of Banggai III. The results of the variance analysis (Test F) are shown in Table 2.

Table 2.

The summary of $\mathrm{F}$ test result (Anova)

\begin{tabular}{lrrrrr}
\hline \multicolumn{1}{c}{ Variance } & \multicolumn{1}{c}{ SS } & \multicolumn{1}{c}{ DF } & \multicolumn{1}{c}{ MS } & $\mathbf{F}_{\text {arithmetic }}$ & $\mathbf{F}_{\text {tab }}$ \\
\hline Regression & 3298,4 & 1 & 3298,4 & 7,78 & 3,89 \\
Residual & 967,5 & 234 & 4,1 & & \\
\hline
\end{tabular}


Information:

SS: The sum of Square

DF: The degree of Freedom $\mathrm{dk}=\mathrm{n}+\mathrm{n}_{2}-2$

MS: The mean of Square

$F_{\text {arithmetic }}$ : The value of $F_{\text {arithmetic }}$

$F_{\text {tab }}:$ The value of $F_{\text {table }}(\alpha=0.05 \%)$

Based on the $\mathrm{F}$ Test results, it was obtained that $\mathrm{F}_{\text {arithmetic }}$ value $>\mathrm{F}_{\text {table }}(0.05)$ which $\mathrm{F}_{\text {arithmetic }}$ is 7.78 and $\mathrm{F}_{\text {table }} 3.89$ at significance level $\alpha=0.05$.

\section{Parent's political affiliation}

The results of the study obtained a regression equation: $\mathrm{Y}=6.68+1.20 \mathrm{X} 3$. The results of the $\mathrm{t}$ test revealed that there was a positive influence from the variable of parental political affiliation on the people's political participation in the Electoral District of Banggai III. The results of the analysis of variance (Test F) are shown in Table 3.

Table 3.

The summary of $F$ test result (Anova)

\begin{tabular}{lrrrrr}
\hline \multicolumn{1}{c}{$\begin{array}{l}\text { Variance } \\
\text { Source }\end{array}$} & \multicolumn{1}{c}{ SS } & \multicolumn{1}{c}{ DF } & \multicolumn{1}{c}{ MS } & $\mathbf{F}_{\text {arithmetic }}$ & $\mathbf{F}_{\text {tab }}$ \\
\hline Regression & 3314,1 & 1 & 3314,1 & 4,73 & 3,89 \\
Residual & 951,8 & 234 & 4,1 & & \\
\hline
\end{tabular}

Information:

SS: The Sum of Square

DF: The Degree of Freedom $\mathrm{dk}=\mathrm{n}+\mathrm{n}_{2}-2$

MS: The Mean of Square

$F_{\text {arithmetic }}$ :The value of $F_{\text {arithmetic }}$

$\mathrm{F}_{\text {tab }}:$ The value of $\mathrm{F}_{\text {table }}(\alpha=0.05 \%)$

Based on the $\mathrm{F}$ test results, it was obtained that $\mathrm{F}_{\text {arithmetic }}$ value $>\mathrm{F}_{\text {table }}(0,05)$ which $\mathrm{F}_{\text {arithmetic }}$ is 4.73 and $\mathrm{F}_{\text {table }} 3.89$ at the significance level $\alpha=0.05$.

\section{Organizational experience}

The results of the research obtained a regression equation: $\mathrm{Y}=3.46+1.02 \mathrm{X} 4$. The result of the $t$ test shows that the variable of organisational experience has a positive influence on the political participation of the people in the Electoral District of Banggai III. The results of the analysis of variance (Test F) are shown in Table 4.

Table 4.

The summary of $F$ test result (Anova)

\begin{tabular}{|c|c|c|c|c|c|}
\hline $\begin{array}{l}\text { Variance } \\
\text { Source }\end{array}$ & SS & DF & MS & $F_{\text {arithmetic }}$ & $F_{\text {tab }}$ \\
\hline Regression & 2543,9 & 1 & 2643,9 & 4,73 & 3,89 \\
\hline Residual & 1622,0 & 234 & 6,9 & & \\
\hline
\end{tabular}

Information:

SS: The Sum of Square

DF: The Degree of Freedom dk $=n+n_{2}-2$

MS: The Mean of Square

$F_{\text {arithmetic }}$ : The value of $F_{\text {arithmetic }}$

$F_{\text {tab }}:$ The value of $F_{\text {table }}(\alpha=0.05 \%)$ 
Based on the $\mathrm{F}$ Test, the results obtained $\mathrm{F}_{\text {arithmetic }}$ value $>\mathrm{F}_{\text {table }}(0.05)$ namely $\mathrm{F}_{\text {arithmetic }}$ of 8.14 and $\mathrm{F}_{\text {table }}$ 3.89 at the significance level $\alpha=0.05$

\section{Knowledge and political awareness}

The results of the research obtained a regression equation, namely: $\mathrm{Y}=8.86+1.10 \mathrm{X} 5$. The results of the $t$ test revealed that there was a positive influence on the variable of public political awareness in the Electoral District of Banggai III. The results of the analysis of variance (Test F) are shown in Table 5.

Table 5.

The summary of $F$ test result (Anova)

\begin{tabular}{lrrrrr}
\hline $\begin{array}{c}\text { Variance } \\
\text { Source }\end{array}$ & \multicolumn{1}{c}{ SS } & \multicolumn{1}{c}{ DF } & \multicolumn{1}{c}{ MS } & $\mathbf{F}_{\text {arithmetic }}$ & $\mathbf{F}_{\text {tab }}$ \\
\hline Regression & 3538,5 & 1 & 3538,5 & 38,21 & 3,89 \\
Residual & 727,5 & 234 & 3,1 & & \\
\hline
\end{tabular}

Information:

SS: The Sum of Square

DF: The Degree of Freedom $\mathrm{dk}=\mathrm{n}+\mathrm{n}_{2}-2$

MS: The Mean of Square

$F_{\text {arithmetic }}$ : The value of $F_{\text {arithmetic }}$

$F_{\text {tab }}:$ The value of $F_{\text {table }}(\alpha=0.05 \%)$

Based on the $\mathrm{F}$ test results, it obtained that $\mathrm{F}_{\text {arithmetic }}$ value $>$ Ftabel (0.05), that $\mathrm{F}_{\text {arithmetic }}$ is 38.21 and $\mathrm{F}_{\text {tabel }} 3.89$ at the significance level $\alpha=0.05$.

\section{Trust in the government}

The results of the study obtained a regression equation: $Y=7.46+1.06 \mathrm{X} 6$. The results of the $t$ test revealed that there was a positive influence on the variable of trust in the government toward the political participation in the Electoral District of Banggai III. The results of the analysis of variance (Test F) are shown in Table 6.

Table 6.

The summary of $F$ test result (Anova)

\begin{tabular}{lrrrrc}
\hline \multicolumn{1}{c}{$\begin{array}{l}\text { Variance } \\
\text { Source }\end{array}$} & \multicolumn{1}{c}{ SS } & \multicolumn{1}{c}{ DF } & \multicolumn{1}{c}{ MS } & $\mathbf{F}_{\text {arithmetic }}$ & $\mathbf{F}_{\text {tab }}$ \\
\hline Regression & 3304,4 & 1 & 3303,4 & 8,31 & 3,89 \\
Residual & 962,5 & 234 & 4,1 & & \\
\hline
\end{tabular}

\section{Information:}

SS: The Sum of Square

DF: The Degree of Freedom $\mathrm{dk}=\mathrm{n}+\mathrm{n}_{2}-2$

MS: The Mean of Square

$F_{\text {arithmetic }}$ : The value of $F_{\text {arithmetic }}$

$F_{\text {tab }}:$ The value of $F_{\text {table }}(\alpha=0.05 \%)$

The obtained $\mathrm{F}$ test results were that $\mathrm{F}_{\text {arithmetic }}$ value $>\mathrm{F}_{\text {tabel }}(0,05)$, with $\mathrm{F}_{\text {arithmetic }}$ at 8.31 and $\mathrm{F}_{\text {tabel }} 3.89$ at the significance level $\alpha=0.05$.

\section{Mass media dissemination and informal discussions}

The results of the research obtained a regression equation: $Y=6.12+1.13 X 7$. The result of the $t$ test show that there is a positive influence from the mass media socialisation and informal discussion 
variable on the political participation in the Electoral District of Banggai III. The results of the analysis of variance (Test F) are shown in Table 7.

Table 7.

The summary of $\mathrm{F}$ test result (Anova)

\begin{tabular}{|c|c|c|c|c|c|}
\hline $\begin{array}{l}\text { Variance } \\
\text { Source }\end{array}$ & SS & DF & MS & $\mathbf{F}_{\text {arithmetic }}$ & $\mathbf{F}_{\text {tab }}$ \\
\hline Regression & 3687,6 & 1 & 3687,6 & 14,91 & 3,89 \\
\hline Residual & 578,3 & 234 & 4,1 & & \\
\hline
\end{tabular}

Information:

SS: The Sum of Square

DF: The Degree of Freedom dk $=n+n_{2}-2$

MS: The Mean of Square

$F_{\text {arithmetic }}$ :The value of $F_{\text {arithmetic }}$

$F_{\text {tab }}$ : The value of $F_{\text {table }}(\alpha=0.05 \%)$

The $\mathrm{F}$ test results obtained that $\mathrm{F}_{\text {arithmetic }}$ value $>\mathrm{F}_{\text {tabel }}(0,05)$ so that $\mathrm{F}_{\text {arithmetic }}$ is 14.91 and $\mathrm{F}_{\text {tabel }} 3.89$ at significance level $\alpha=0.05$. Furthermore, related to the results of the inferential analysis (multiple regression) where the independent variables (X1, X2 ... X7) simultaneously influence the dependent variable $(\mathrm{Y})$ or other variables that being controlled it can be seen that the results showed that there are 3 variables that are greater than the 4 other independent variables. The results of the analysis with the help of the Minitab 16 program show that the value of a constant is 11.45 , so the highest effect is $\mathrm{X} 4$ of 0.92 ; $\mathrm{X} 1$ is 0.57 ; and $\mathrm{X} 7$ is 0.51 . The multiple regression equation is as follows:

$$
Y=11,45+0,572 X 1+0,175 X 2+0,162 X 3+0,922 X 4+0,255 X 5+0,243 X 6+0,510 X 7
$$

To find out whether the multiple regression equation is significant or not, the testing ofthe variance analysis (Test F) was carried out. The criteria used were $F_{\text {arithmetic }} \geq F_{\text {tabel }}(0.05)$. The results of the $F$ test analysis are shown in Table 8 .

Table 8.

The summary of $F$ test result (Anova)

\begin{tabular}{|c|c|c|c|c|c|}
\hline $\begin{array}{c}\text { Variance } \\
\text { Source }\end{array}$ & ss & DF & MS & $\mathbf{F}_{\text {arithmetic }}$ & $F_{\text {tab }}$ \\
\hline Regression & 76829 & 7 & 10976 & 91,13 & 3,89 \\
\hline Residual & 273 & 229 & 1 & & \\
\hline
\end{tabular}

Information

SS: The Sum of Square

DF: The Degree of Freedom dk $=\mathrm{n}+\mathrm{n}_{2}-2$

MS: The Mean of Square

$F_{\text {arithmetic }}$ : The value of $F_{\text {arithmetic }}$

$F_{\text {tab }}:$ The value of $F_{\text {table }}(\alpha=0.05 \%)$

Based on the $\mathrm{F}$ Test, the results obtained were $\mathrm{F}_{\text {arithmetic }}$ value $>\mathrm{F}_{\text {tabel }}(0,05)$ that $\mathrm{F}_{\text {arithmeti }} \mathrm{c}$ is 91.13 and $\mathrm{F}_{\text {tabel }}$ 3.89 at the significance level $\alpha=0.05$. This means that there is a positive and significant effect from the variable X123 ...7 simultaneously towards the dependent variable (Y). Thus, the H1 hypothesis is accepted and rejected by Ho. This means that there is a positive and significant influence from the variables such as the social and economic status of the community, situation/geography, parental political affiliation, organisational experience, political awareness, trust in the government, and mass media socialisation as well as informal discussions towards people's political participation. The results of this study imply that the variables that have been analysed and tested have a positive and significant influence related to increasing people's political participation. If these variables are increased by 1 unit, then it will increase community participation by 14.3 . 


\section{The increasing of public political participation model in general elections}

In terms of this research, in order to increase people's political participation, the most significant model, especially in the Electoral District of Banggai III, is as follows.

\section{The increasing of social and economic status}

Social status is the position of an individual in the community based on their family status, education and work. The economic status is the condition of an individual measured based on their ownership of wealth in the social environment. An individual who has a high social status in society will likely have political knowledge, and an interest in politics (Surbakti 1992). From this perspective, in order to increase the people's political participation, the Local Government should increase its public social status by making various effective and efficient breakthroughs to provide political and/or formal education to the community, especially for people who do not usually cast a ballot. An adequate political understanding in accordance with people's needs is a significant strategy to increase political participation.

In addition, it is the duty of the Local Government to improve the economic standard of living of society. This should not just become a regular slogan or jargon, but real action through a concrete economy-based model program is needed. Most of individuals will likely to have some sort of instinct to improve their family financial ability, however, the capital problem is in the way. Both modal capital and proper training are the things that they need in every sector of the economic aspect such as agriculture, fisheries, handicrafts and supporting entrepreneurs. The local government should provide a method to overcome these obstacles by involving experts or professionals. Hence, there is a local government trajectory project to increase the social and economic status of its people so then they become more active in political activities as well as in the election.

\section{The increasing of geographical access}

The geographical factors such as weather, family condition, the existence of other individuals/ opinions, time and space atmosphere and threat will likely influence the people's decision when casting a ballot. The local government, $K P U$ and all of the stakeholders involved need to find out the best solution to fix these situations at the local context. From previous experience, it shows that those who live in a good geographical condition tend to be more attentive and caring in relation to channelling their political aspirations. However, for those who live in an isolated area far from the city, the road, as well as bridges and where the river and the sea is the only way that they can get in touch with other people. By living in a less fortunate family, this kind of condition will make them easily swayed with only a little pressure from another party, causing them to abstain from the election. Furthermore, security and safety factors are an absolute condition which should be guaranteed by the national army and police (TNI/POLRI) voluntarily at every election. Geographical conditions which are less favourable greatly affect the desire of the citizens to participate in the elections. This condition is definitely a concern of the General Election Commission (KPU) of Banggai Regency. There should be a concrete long-term plan to prevent this happening in the future as well as a plan to improve the geographical situation of that area.

\section{The empowerment of community groups and political affiliations}

Affiliation is an action of individual when joining a group or community. Political affiliation can be formulated as membership or collaboration carried out by individuals or groups involved in certain political streams. Political affiliation encourages the improvement of political awareness and maturity at the individual level, encouraging the individual to use their political rights freely and responsibly when carrying out various political activities such as participating in political parties in the government, and participating in the process of taking part in and implementing political decisions. This political affiliation has a considerable influence on determining whether people will be involved in the election and use their political aspiration or vice versa. A less supportive political affiliation will affect the political choices of the people. Furthermore, the majority of the people stated that 
their desire to use their political aspirations was largely influenced by their family's point of views (the political affiliation of their parents) in relation to determining who they would choose in the legislative elections, the Presidential Election, and the Regional Head Elections. The study showed that the information they receive about the procedures for channelling their political aspirations and their ignorance of who the elected candidates are will increase the number of the abstentions. Therefore, political education for parents and young constituents about the election mechanisms and procedures is important to provide the information that democracy is important.

\section{The increasing of community organisation experience}

An organisation is a system that regulates people's lives or that can be interpreted as a patterned behaviour by providing a position for certain people to carry out their functions to achieve common goals (Hendrik, 2010). According to this research, organisational experience has a positive and significant impact in terms of political participation in the Banggai III electoral district. In connection, the local government and the $K P U$ should pay more attention to society by creating both formal and informal institutions providing sustainable development for society in this region, especially in the Banggai III electoral district. Since the local government and KPU have never created such institutions as an electoral machine to increase people's understanding and knowledge regarding the general election, this method is considered ineffective. However, these forums tend to be created and formed around the election period. Such a program should be simultaneously held to enhance people's knowledge further, especially related to casting ballots and using their vote as one way to implement their political aspirations.

\section{The increasing of public political awareness}

According to the various scientific journals and literature, community political awareness is the level of awareness of the citizens in relation to using their rights and obligations regarding the knowledge of a person about politics and society. It also includes the people's interest toward the community and the political environment around them. This research shows that the people's political awareness has a greater positive and significant impact toward the political participation of society. This means that the higher the political awareness of the people, the higher the people's political aspiration. This can be done through several strategies, including providing sustainable political education to society. This activity is an activity that systematically and sustainably builds and developed. Since the socialisation or workshop regarding this matter is considered to be important, the existence of these activities must be held under the supervision of the KPU of Banggai Regency in order to provide political education to society. According to the society of Banggai Regency, most on the permanent voter list were not involved in such activities. Hence, these people tend not to use their political rights due to their lack of information regarding the candidates, especially in remote areas where direct socialisation is needed. In consequence, the cooperation between the local government and the $K P U$ should provide political education, especially for the people in the Banggai III electoral district. In addition, the low political participation of Banggai III society is caused by several problems such as the incorrect data recording in this regard and the quantitative permanent voter list (DPT). This caused an enormous amount of people to lose their right to cast a ballot in the last legislative election. Regarding this matter, the local government, $K P U$ and the political parties of the Banggai III Regency should find an effective method of voter data recording to prevent this happening in the next election.

\section{The increasing of public trust in the Regional Government and DPRD}

The low public perception toward the performance of the local government and the legislative institution have a great influence on society relating to casting a ballot in the elections, both presidential and legislative. This study shows that the public trust towards the local government (Regent, Deputy Regent, Regional People's Representative Assembly) DPRD and the General Election Commission $(K P U))$ has a positive and significant influence toward people's political participation. Therefore, it is deemed necessary to improve the performance of the local government so then the community is more confident and aware of channelling its aspirations. 
This biased perceptions can be refuted by improving local government performance. Both the local government and the KPU should publish their accomplishments, long-term trajectory targets, and what the implications will be of these improvement towards the socio-economic life of society in the region using direct and indirect methods such as mass media and direct socialisation in remote areas. There has been a high amount of scepticism over the local government's performance especially in the Banggai III electoral district over the years. Thus, the local government should pay more attention as well as support for society in this region, providing them with an understanding of and insightful knowledge into the election as well as the government's performance. As a consequence, it is expected that the political participation in this region will increase simultaneously, especially in the Banggai III Electoral District and for the Banggai Regency in general.

\section{Mass media empowerment and informal discussions}

The people's politic participation is determined by the mass media and informal discussion support. The research shows that mass media and informal discussions have a great and significant influence toward participation in politics, especially concerning the elections of the Banggai III Regency. Therefore, the involvement of mass media is one of the most effective methods used by the KPU in Banggai III Regency to provide political understanding and knowledge about the elections to society in general. As a forum in providing information, mass media should provide valid and objective information, hence $K P U$ should create a conducive space for the local mass media and become their partner, supporting the programs that have been established by the KPU. In addition, the Local Government and $K P U$ need to create a public space to provide input about the problems faced by the community in relation to the implementation of the general election. A systematic and effective informal discussion should be provided and carried out on an ongoing basis simultaneously to achieve the expected goals. The existing mass media in this region could be an inspirational source for the people regarding political and strategic improvements and developments in the general election. In consequence, to ensure that legislative elections, presidential elections, and post-conflict local elections run in an orderly, safe and sound manner, this step is considered to be important to conduct. Finally, the people will voluntarily take a pro-active role in their political aspirations.

\section{Conclusion}

It can be stated that the factors which influence the political participation of the people in the Electoral District of Banggai III consist of seven theory-based variables as follows: 1) the social and economic status of the community has a positive and significant impact on the political participation of the people in the Electoral District of Banggai III with a regression coefficient Ý $=9.64+1.16$ $\mathrm{X} 1$; 2) the geographical situation has a positive and significant effect on the political participation of the people in the Electoral District of Banggai III with a regression coefficient $Y=8.13+1.10$ $\mathrm{X} 2$; 3) parental affiliation has a positive and significant impact on the political participation of the community in the Electoral District of Banggai III with a regression coefficient $Y=6.68+1.20 \mathrm{X} 3$; 4) organisational experience has a positive and significant effect on the political participation of the people in the Electoral District of Banggai III with a regression coefficient Ý $=3.46+1.02 \mathrm{X} 4 ; 5$ ) knowledge and political awareness has a positive and significant effect on the political participation of the people in the Electoral District of Banggai III with a regression coefficient Ý $=8.86+1.10$ $\mathrm{X} 5$; 6) trust in the Government has a positive and significant effect on the political participation of the people in the Electoral District of Banggai III with a regression coefficient Ý $=7.46+1.06$ X6; and 7) mass media socialisation and informal discussions have a positive and significant effect on the political participation of the people in the Electoral District of Banggai III with a regression coefficient $Y=6.12+1.13 \mathrm{X} 7$. The results of the multiple regression analysis and partial correlation indicate that the variables that are likely to have a high influence are X1 (social and economic status of the community), X4 (experience of community organisation), and X7 (trust in the government). Thus it can be concluded that the variables of the social and economic status of the community, the experience of community organisation, and the trust in the government should be a serious concern for the Regional Government and $K P U$. The three variables can be increased in importance, which should lead to the increased political participation of the Electoral District of Banggai III. 
The efforts made to follow up on the political participation of the community in the general election include models that are able to provide positive nuances such as: 1) increased social and economic status, 2) increased access to geographical situations, 3) empowerment of community groups and political affiliations, 4) increased experience of community organisation, 5) increased political awareness of the community, 6) increased public trust in the Regional Government and $D P R D$, and 6) empowerment of mass media and informal discussions.

\section{References}

Abdussamad J, Akib H, \& Paramata J (2015) Effect of transformational leadership and organizational culture on employee performance toward The Department of Education, Youth and Sports Gorontalo Province, Indonesia. International Journal of Academic Research 7 (1).

Akib H \& Salam R (2016) Analisis kualitas pelayanan publik berbasis Importance Performance Analysis (IPA) pada Kecamatan Kota Makassar. Jurnal Ilmiah Scientific Pinisi 2 (April 2016):16-20.

Arikunto S \& Jabar CSA (2009) Evaluasi Program Pendidikan: Pedoman Teoritis Praktis Bagi Mahasiswa dan Praktisi Pendidikan. Jakarta: Bumi Aksara.

Creswell JW (2014) Research Design: Qualitative, Quantitative, and Mix Methods Approaches (Fourth). Los Angeles, USA: Sage Publications.

Effendi A (2017) Studi komparatif pengaturan sistem pemilihan umum anggota Dewan Perwakilan Rakyat di Indonesia. Fiat Justisia 10 (2).

Eriyanto A (2007) Teknik Sampling. Yogyakarta: PT. LKiS Pelangi Akasa.

Farida U (2017) Analysis of empowerment program that was implemented in Mamuju Regency East Sulawesi Indonesia 149 (Icest):19-21.

Goodnow FJ (2017) Politics and Administration: A Study in Government. Routledge.

Hendrik D (2010) Variabel-variabel yang mempengaruhi rendahnya partisipasi politik masyarakat dalam Pilkada Walikota dan Wakil Walikota Padang tahun 2008. Jurnal Demokrasi 9 (2).

Holik I (2012) Komunikasi politik dan demokratisasi di Indonesia: Dari konsolidasi menuju pematangan. Jurnal FISIP: MADANI 2 (02).

Humaeni A (2014) Penggunaan magic dalam politik lokal di Banten. Masyarakat, Kebudayaan dan Politik 27 (1):14-26.

Mulyadi R \& Amin RM (2017) Perilaku pemilih dalam pemilihan wali Nagari di Kenagarian Rabi Jonggor, Gunung Tuleh, Pasaman Barat, Sumatera Barat tahun 2014. Jurnal Online Mahasiswa (JOM) Bidang Ilmu Sosial dan Ilmu Politik 5 (1):1-15.

Murdi L \& Salam R (2012) Fenomena Birokrasi Di Era Soeharto (Sebuah Analisa Kecendrungan Birokrasi Pada Masa Orde Baru). Seminar Nasional Reformasi Birokrasi Menuju Tata Kepemerintahan Yang Baik (Vol. 1). Program Doktor Ilmu Administrasi Publik.

Niswati R (2015) Demokratisasi dan Efektivitas Penyelenggaraan Pemilihan Kepala Daerah Kabupaten Gowa Oleh Komisi Pemilihan Umum Daerah. Universitas Negeri Makassar.

Prasetyoningsih N (2014) Dampak Pemilihan Umum serentak bagi pembangunan demokrasi Indonesia. Jurnal Media Hukum 21 (2):23.

Saggaf S, Salam R, Kahar F, \& Akib H (2014) Pelayanan fungsi administrasi perkantoran modern. Jurnal Ad'ministrare 1 (1):20-27.

Sahab A (2017) Realitas citra politik Tri Rismaharini. Masyarakat, Kebudayaan dan Politik 30 (1):20-33.

Salam R, Rosdiana, Suarlin, \& Akib H (2014) The Impact of Policy on Region Expansion to Office Administrative Services in Barombong Substrict of Gowa District. In International Conference on Mathematics, Science, Technology, Education and their Applications (ICMSTEA) 2014. 
Saraswati R (2014) Reorientasi hukum Pemilukada yang mensejahterakan rakyatnya. Jurnal Dinamika Hukum 14 (2):359-367.

Sarwono J (2006) Metode Penelitian Kuantitatif Kualitatif. Yogyakarta: Graha Ilmu.

Setio SE (2014) Hak Recall Partai Politik terhadap Keanggotaan DPR dalam Sistem Ketatanegaraan Indonesia. Thesis.

Sugiyono (2010) Metode Penelitian Pendidikan (Pendekatan Kuantitatif, Kualitatif, dan R\&D). Bandung: CV Alfabeta.

Supriyanto D (2014) Kajian Kodifikasi Undang-Undang Pemilu. Jakarta: Yayasan Perludem.

Surbakti RA (1992) Interrelation between Religious and Political Power Under New Order Indonesia.

Trantidis A (2017) Is Government Contestability an Integral Part of the Definition of Democracy? Politics 37 (1):67-81.

Waiswa M \& Phelps M (2017) Empowering women: A case study of women's participation in political processes in Nakuru County. Theses, University of Minnesota Digital Conservancy. http://hdl.handle.net/11299/190784.

Wanma AV (2015) Pentingnya pendidikan politik generasi muda terhadap pelaksanaan partisipasi politik di Distrik Samofa Kabupaten Biak Numfor. JURNAL POLITICO 2 (6). 